\title{
Case Study of Workplace Spirituality on Organizational Commitments among University Members in Malaysia
}

\author{
Thamil Durai Chelliah* \\ Faculty of Business and Finance, Universiti Tunku Abdul Rahman, \\ Malaysia

\section{Ling-Meng, Chan} \\ Faculty of Business and Finance, Universiti Tunku Abdul Rahman, \\ Malaysia

\section{Mathivannan Jaganathan} \\ School of Business Management, Universiti Utara Malaysia, \\ Malaysia

\section{Ying-Yin, Koay} \\ Faculty of Business and Finance, Universiti Tunku Abdul Rahman, \\ Malaysia
}

*Corrosponding author's thamildc@utar.edu.my

\section{Research High Iight s}

Based on the recent past studies (Ahmad \& Omar, 2015; Ke \& Deng, 2018; Ghani, Abdullah $\&$ Allah, 2018), there are an increasing attention from the researchers to examine the workplace spirituality in the organization. This research study seeked to study the influences of workplace spirituality (Allen \& Meyer , 2000) on organizational commitments among university members in Malaysia. Data of 240 responses were collected and analyzed via partial least square structural equation modelling to examine both the measurement and structural model. It is significantly accentuated that workplace spirituality influences the three dimensions of organizational commitment. From this empirical findings, it strongly suggested that the university shold find ways to embded this workplace spirityality into university members' performance in order to enhance the loyalty and employee engagement with the university (Alas \& Mousa, 2016).

This study has proposed three hypothesis and results indicated that there is a significant relationship between workplace spirituality on the three dimensions of organizational commitment. With increasing the spirituality of employees towards their workplace, it can enhance the loyalty and motivation for employee to stay in the organization. 


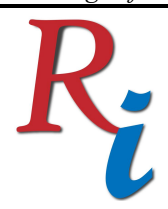

\section{Asia Proceedings of Social Sciences}

(APSS)

www.readersinsight.net/APSS

\section{G r a p h i c a I A b s t r a c t (optional)}

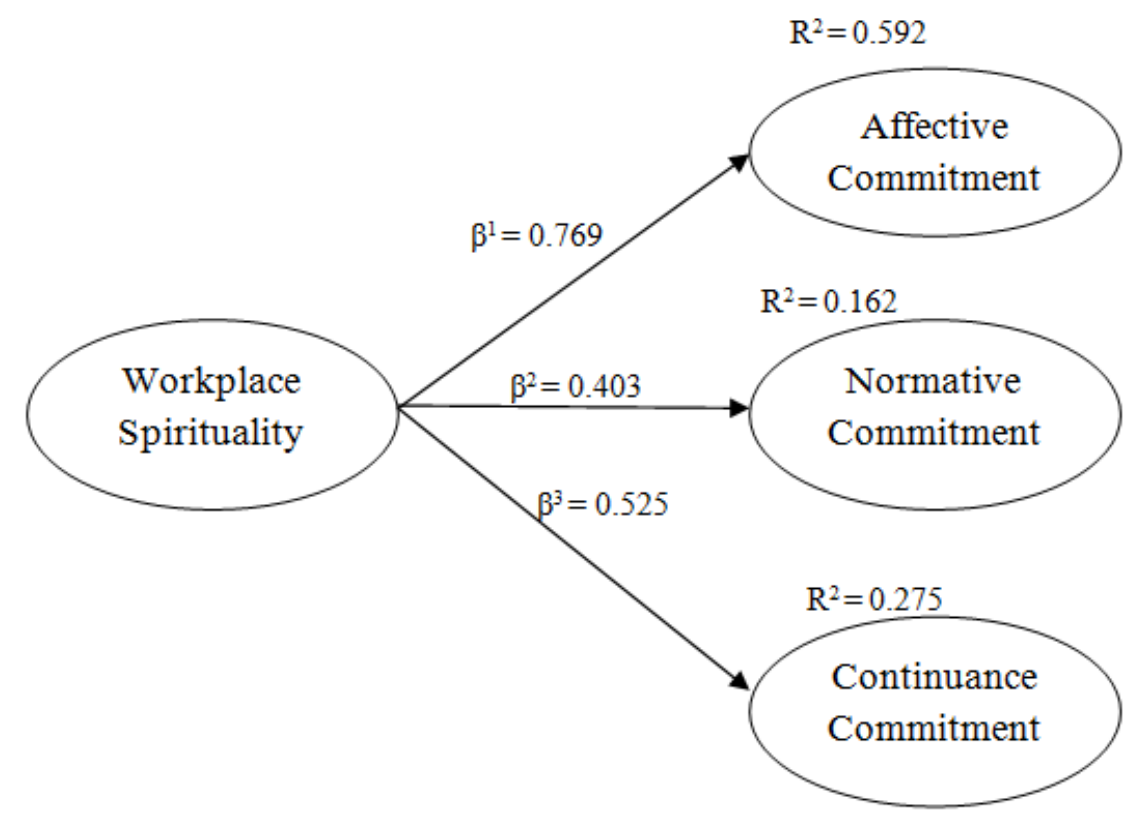

\section{Research Objectives}

Most of the employees nowadays are seeking the importance and the connotation of their job related task (Neck \& Milliman, 1994). They tended to be more positive and more committed towards their job and their organziation if they are involved in heavility spirituality organizational climates (Chan, Abd. Wahat, Mohd. Rasdi \& Ismail, 2017). It is consistent with the study of Ghani, Abdullah \& Allah (2018), where in an altruistic love work culture, it can help to boost employees' commitment and attachement towards their organizationa. Hence, this study aimed to examine the influences of workplace spirituality on the organizational commitments among the university members.

\section{Methodology}

This study employed quantitative research design to study the relationship between workplace spirituality and organizational commitment. Self administrated survey method was used for data collection. Total of 240 data were collected from five different regions in Malaysia, from both public and private universities. Majority of the respondents are female ( $\mathrm{n}$ 


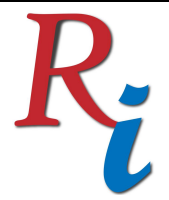

\section{Asia Proceedings of Social Sciences}

(APSS)

www.readersinsight.net/APSS

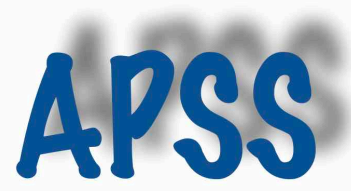

$=140,58.33 \%)$. Furthermore, the respondents were also grouped based on their working experiences in the university: 1 to 5 years $(n=39,16.25 \%) ; 6$ to 10 years $(n=77,32.08 \%)$; 11 to 15 years $(\mathrm{n}=80,33.33 \%) ; 16$ to 25 years $(\mathrm{n}=38 ; 15.83 \%)$; and above 20 years $(\mathrm{n}=6$, $2.50 \%$ ). The majority of respondents for this research study are academicians $(\mathrm{n}=140$, $58.33 \%)$ and the respondents are from private and public universities respectively $(\mathrm{n}=120$, $50.00 \%)$

\section{Results}

Based on the measurement model assessment, all four constructs (affective commitment, continuous commitment, normative commitment and workplace spirituality) have adequate consistency reliability, and their convergents were well confirmed and satisfied. From the structural model, it indicated that workplace spirituality is able to explain $59.2 \%, 27.5 \%$ and $16.2 \%$ respectievely towards the three dimensions of roagnizational commitment ((affective commitment, continuous commitment, and normative commitment) and it is also found significantly correlated with these three dimensions: $\mathrm{AC}(\beta=0.769, \mathrm{p}<0.05)$; $\mathrm{CC}(\beta=0.525$, $p<0.05)$; and NC $(\beta=0.403, p<0.05)$. Besides that, the findings also implied that the proposed model has sufficient predictive relevance. Analogously, the workplace spirituality is able to predict the three dimensions of organizational commitment among university members. The degree of predictive relevance for this model in the dimension of affective commitment is the largest compare with the other two dimensions, with the effect size of medium as the Stone - Geisser's values

\section{Findings}

Based on the findings of the study, it indicated that workplace spirituality does play an important role in influencing university members' organizational commitment. Through the findings, it showed that workplace spirituality is significantly correlated with the three dimensions of organizational commitment (affective commitment, continuative and normative commitment) with different correlation strength. This suggested that the different dimension of spirituality are in different form of construct compared to the organizational commitment and this indicated that it is applicable in research as two different sets of variables.

Moreover, the workplace spirituality has emerged under the most dominant variable to predict the university members; organizational commitment towards their university, if the work culture is allow the university members to perform the meaningful work and work in group, it is enable the members to enhance their likelihood of reaching full capacity and 


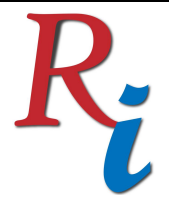

\section{Asia Proceedings of Social Sciences}

(APSS)

www.readersinsight.net/APSS

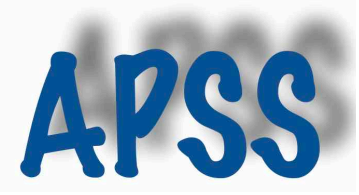

realizing full potential at work. This subsequently can lead to better and higher work performance with better work quality performed by the university members, and resulted less turnover rate.

\section{References}

Ahmad, A., \& Omar, Z. (2015). Improving Organizational Citizenship Behavior through Spirituality and Work Engagement. American Journal of Applied Sciences, 12(3), 200-207. Http://Dx.Doi.Org/10.3844/Ajassp.2015.200.207

Alas R, Mousa M (2016). Organizational Culture and Workplace Spirituality. Int. J. Emerg. Res. Manage. Technol. 5(3)

Allen NJ, Meyer JP (2000). Construct Validation In Organizational Behavior Research: The Case Of Organizational Commitment. In Guftin, R.D and Helmes, E. Problems and Solutions In Human Assessment: Honoring Douglas N. Jackson At Seventy, Kluwer, Norwell, MA. Pp. 285-314

Chan, LM, Abd. Wahat, Wahiza, Mohd Rasdi, R., \& Ismail, I. (2017). The Role Of Religiosity And Ethical Climate On Hotelier: A Conceptual Study On Ethical Decision Making. Journal of Global Business and Social Entrepreneurship (GBSE), 3(7).

Ghani, A., Abdullah, K., \& Allah, A. (2018). Workplace Spirituality Enhance Organizational Commitment In The School Management.

Ke, J., \& Deng, X. (2018). Family-Friendly Human Resource Practice, Organizational Commitment, and Job Performance among Employees: The Mediating Role of Workplace Spirituality. Journal of Human Resource and Sustainability Studies, 6(01), 81.

Neck, C. P., \& Milliman, J. F. (1994). Thought Self-Leadership: Finding Spiritual Fulfilment In Organizational Life. Journal Of Managerial Psychology, 9(6), 9-16.

Peer-review under responsibility of $4^{\text {th }}$ Asia International Conference 2018 editorial board (http://www.utm.my/asia/our-team/) (C) 2018 Published by Readers Insight Publisher, lat 306 Savoy Residencia, Block 3 F11/1,44000 Islamabad. Pakistan, info@readersinsight.net This is an open access article under the CC BY-NC-ND license (http://creativecommons.org/licenses/by-nc-nd/4.0/). 